\title{
Transgenic Brain-Derived Neurotrophic Factor Modulates a Developing Cerebellar Inhibitory Synapse
}

\author{
Shaowen Bao, Lu Chen, Xiaoxi Qiao, and Richard F. Thompson ${ }^{1}$ \\ Neuroscience Program \\ University of Southern California \\ Los Angeles, California 90089-2520 USA
}

\begin{abstract}
Brain-derived neurotrophic factor (BDNF) has been shown to promote synapse formation and maturation in neurons of many brain regions, including inhibitory synapses. In the cerebellum, the Golgi cell-granule cell GABAergic synaptic responses undergo developmental transition from slow-decaying to fast-decaying kinetics, which parallels a developmental increase of $\mathrm{GABA}_{\mathrm{A}}$ receptor $\alpha 6$ subunit expression in the cerebellar granule cells. In culture, BDNF accelerates the expression of $\mathbf{G A B A}_{A}$ receptor $\alpha 6$ subunit expression in granule cells. Here we examined synaptic $\mathbf{G A B A}_{\mathbf{A}}$ response kinetics in $B D N F$ transgenic mice. The mutant mouse, which carries a BDNF transgene driven by a $\beta$-actin promoter, overexpresses BDNF (two- to fivefold increase compared with wild types) in all brain regions. Recordings of the spontaneous $\mathrm{GABA}_{\mathrm{A}}$ responses indicate that the decay time constant of the GABAergic responses decreases during early postnatal development; this transition is accelerated in the BDNF transgenic mouse. The amplitude of the spontaneous GABA $_{A}$ responses was also larger in the transgenic mouse than in the wild-type mouse. However, the frequency of the spontaneous $\mathrm{GABA}_{\mathrm{A}}$ responses were not different between the two groups. Our results suggest that BDNF may modulate GABAergic synapse maturation in the cerebellum.
\end{abstract}

\section{Introduction}

Brain-derived neurotrophic factor (BDNF), along with other members of the neurotrophin family, was first identified as one of the classical survival proteins in developing mammalian nervous system (Ghosh et al. 1994; Kubo et al. 1995; Nonomura et al. 1996). The expression of BDNF exhibits a unique temporal pattern. Whereas the expression levels of most other neurotrophic factors (e.g., nerve growth factor, neurotrophin 3) in many brain regions decrease during postnatal development, BDNF expression becomes prominent only after neurogenesis has occurred and stays at high levels in the mature central nervous system (CNS) (Leibrock et al. 1989; Maisonpierre et al. 1990; Rocamora et al. 1993). Concomitant with its expression pattern, BDNF was found to regulate events that occur during late stages of neuron development, such as dendritic growth and synaptic innervation (Gao et al. 1995; McAllister et al. 1995; Bartrup et al. 1997; Causing et al. 1997; Rutherford et al. 1998; Vicario-Abejon et al. 1998). BDNF has been shown to modulate GABAergic neurons and synapses. In culture, BDNF increases GABA content and glutamic acid decarboxylase (GAD) activity level in neostriatal (Mizuno et al. 1994; Ventimiglia et al. 1995) and neocortical neurons (Rutherford et al. 1997), and increases GABA uptake and soma size of cortical interneurons (Widmer and Hefti 1994). In BDNF transgenic mice, GAD65 and parvalbumin expression revealed accelerated emergence of the mature pattern of inhibitory presynaptic boutons in the visual cortex (Z.J. Huang, A. Kirkwood, V. Porciatti, T. Pizzorusso, M.F. Bear, L. Maffei, and S. Tonegawa, unpubl.). In addition to its modulatory effects on presynaptic GABAergic neurons, BDNF also accelerates the expression of postsynaptic $\mathrm{GABA}_{\mathrm{A}}$ receptor subunits in cerebellar granule cell culture (Lin et al. 1998). However,

${ }^{1}$ Corresponding author.

LEARNING \& MEMORY 6:276-283 @ 1999 by Cold Spring Harbor Laboratory Press ISSN1072-0502/99 \$5.00

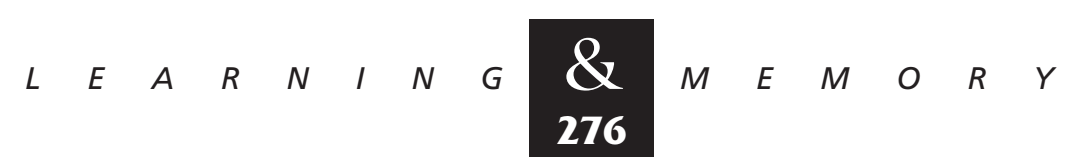


these studies are more or less limited to biochemical and morphological characterization (but see Rutherford et al. 1998; Vicario-Abejon et al. 1998), largely due to a lack of electrophysiological assessment of GABAergic synapse development.

In the cerebellar cortex, the initial formation of inhibitory synapses between Golgi cells and granule cells occurs after granule cells migrate into the internal layer. The internal granule cells express a subset of $\mathrm{GABA}_{\mathrm{A}}$ receptor subunits, and the receptor composition undergoes a developmental transition during the process of GABAergic synapse maturation (Laurie et al. 1992; Zheng et al. 1993; Fritschy et al. 1994; Thompson and Stephenson 1994). For example, the mRNA signal for the $\alpha 6$ subunit of the $\mathrm{GABA}_{\mathrm{A}}$ receptor is not present until the end of the first postnatal week and is fully expressed only in granule cells exhibiting mature (i.e., fast-decaying; see Tia et al. 1996; L. Chen, S. Bao, X. Qiao, and R.F. Thompson, unpubl.) GABAergic synaptic responses (Zheng et al. 1993). Interestingly, application of BDNF accelerated $\alpha 6$ subunit expression in cultured cerebellar granule cells (Lin et al. 1998), suggesting that BDNF may modulate cerebellar GABAergic synapse maturation. In the current study, taking advantage of transgenic mice, we studied the effects of BDNF on developing cerebellar Golgi cell-granule cell synapses.

\section{Materials and Methods}

ANIMALS

BDNF transgenic mouse was generated (at Regenrenon Pharmaceuticals Inc.) with germ-line insertion of a human $B D N F$ transgene (Croll et al. $1999)$ driven by a $\beta$-actin promoter. Heterozygous transgenic mice $(\mathrm{C} 57 \mathrm{BL} / 6 \times \mathrm{DBA} / 2)$ were used to breed homozygous, heterozygous, and wild-type littermates (at a University of Southern California vivarium). Both homozygotes and heterozygotes, were pooled as transgenics, whereas wild types and some age-matched $\mathrm{C} 57 \mathrm{BL} / 6$ inbreds were used as controls. As both homozygote and heterozygote exhibit normal phenotype, the experiments were conducted blindly with experimenters unaware of the genotypes of the mice. Genomic Southern blot analysis was used to identify the BDNF transgene.

\section{HISTOLOGY}

Transgenic and age-matched wild-type mice were deeply anesthetized with Halothane, and transcardially perfused with $0.9 \%$ saline and $10 \%$ buffered formalin. The brains were removed and postfixed in $10 \%$ formalin for at least $24 \mathrm{hr}$. Then the brains were sliced with a sliding microtome. Parasagittal sections $(40 \mu \mathrm{m})$ were mounted onto gelatin-coated slides, stained with cresyl violet, and observed with light microscope.

\section{IN SITU HYBRIDIZATION AND NORTHERN BLOTS}

The procedures for in situ hybridization and Northern blots were the same as in Qiao et al. (1996). Briefly, brains from both wild-type and mutant adult mice were excised after decapitation, frozen on dry ice, sliced on a cryostat at $16 \mu \mathrm{m}$, and mounted on subbed slides. The mutant and wildtype brain sections were mounted on the same slides and processed identically for optimal comparison. The sections were fixed with $4 \%$ p-formaldehyde in $0.1 \mathrm{M}$ PBS for $30 \mathrm{~min}$ and pretreated with $0.25 \%$ acetic anhydrite and $0.1 \mathrm{~m}$ triethanolamine for $10 \mathrm{~min}$. Then, the tissue sections were incubated overnight at $50^{\circ} \mathrm{C}$ with ${ }^{35} \mathrm{~S}$-labeled riboprobe $\left(5 \times 10^{6} \mathrm{cpm} / \mathrm{ml}\right)$ prepared from a pGEM- $4 \mathrm{Z}$ plasmid containing a 460-bp insert of rat BDNF cDNA clone (Phillips et al. 1990). The hybridization solution also contains 50\% formamide, 10\% dextran sulfate, $300 \mathrm{~mm} \mathrm{NaCl}, 0.5 \mathrm{mg} / \mathrm{ml}$ yeast RNA, $10 \mu \mathrm{M}$ dithiothreitol, $0.02 \%$ Ficoll, 0.02\% polyvinyl pyrrolidone, 0.02\% BSA, 1 mm EDTA, and $10 \mathrm{~mm}$ Tris- $\mathrm{HCl}$ ( $\mathrm{pH} \mathrm{8.0)}$. After hybridization, the sections were rinsed in $4 \times$ SSC, digested with 20 $\mu \mathrm{g} / \mathrm{ml} \mathrm{RNase} \mathrm{A}$ at $37^{\circ} \mathrm{C}$ for $30 \mathrm{~min}$, and washed through descending concentrations of $1 \times$ SSC to $0.1 \times$ SSC at $60-70^{\circ} \mathrm{C}$. Finally, the slides were dehydrated in ethanol, dried, and exposed to X-ray film (Kodak X-Omat, Rochester, NY) for 3-5 days.

For Northern blots, total RNA was extracted from mice cerebella with RNA/DNA protein isolation TRI Reagent (Molecular Research Center, Cincinnati, OH). Briefly, the cerebellum of each animal was homogenized in TRI Reagent solution, suspended in a 1:5 volume of chloroform, and centrifuged at $12,000 \mathrm{~g}$ for $15 \mathrm{~min}$. The RNA contained in the aqueous phase was transferred and precipitated with isopropanol. The samples were then centrifuged at $12,000 \mathrm{~g}$ for $15 \mathrm{~min}$ to pellet the RNA. After being washed with $75 \%$ cold ethanol, the pellet was dissolved in RNase-free water. The total RNA $(20 \mu \mathrm{g})$ was separated by standard methods on a formaldehyde-denaturing agarose gel. The RNA was then blotted to neutral nylon membranes (Max-Strength Nytran, Schleicher \& Schuell,

$$
\begin{array}{llllllllllllllll} 
& E & A & R & N & I & N & G & \boldsymbol{\bigotimes} \\
\mathbf{2 7 7} & M & E & M & O & R & Y
\end{array}
$$


Keene, $\mathrm{NH}$ ) and hybridized to random prime ${ }^{32} \mathrm{P}$ labeled $B D N F$ cDNA probe $\left(\sim 3 \times 10^{6} \mathrm{cpm} / \mathrm{ml}\right.$; Strategene, La Jolla, CA). The membrane was then washed in graded SSC, dried, and exposed to PhosphorImager plates (Molecular Dynamics, Eugene, OR). Relative abundance of mRNA was quantified by reading the plates. For accurate quantification, the same blot was stripped off and hybridized to ${ }^{32}$ P-labeled $\beta$-actin probe. The ratio of $\mathrm{BDNF} / \beta$-actin optical densities was then used for comparison.

\section{BRAIN SLICES}

The mouse was decapitated, the cerebellum removed and placed in ice-cold artificial cerebrospinal fluid (ACSF: $124 \mathrm{~mm} \mathrm{NaCl}, 3 \mathrm{~mm} \mathrm{KCl}, 1.25$ $\mathrm{mm} \mathrm{KH}_{2} \mathrm{PO}_{4}, 2.5 \mathrm{~mm} \mathrm{CaCl}_{2}, 1.3 \mathrm{~mm} \mathrm{MgCl}, 26 \mathrm{~mm}$ $\mathrm{NaHCO}_{3}, 10 \mathrm{~mm}$ glucose, buffered with $5 \% \mathrm{CO}_{2}$ and $\left.95 \% \mathrm{O}_{2}\right)$. The cerebellar vermis was sliced sagittally $(400 \mu \mathrm{m})$ with a vibrotome. The slices were incubated in ACSF for at least $30 \mathrm{~min}$ before being transferred into a submersion recording chamber. Incubations and all subsequent experiments were done at room temperature.

\section{ELECTROPHYSIOLOGY}

Spontaneous $\mathrm{GABA}_{\mathrm{A}}$ currents of granule cells were recorded with whole-cell configuration, and the blind techniques (Blanton et al. 1989) were used to form tight seals. The impedance of the patch pipettes ranges from 3 to $6 \mathrm{M} \Omega$ when filled with internal solution (140 mM CsCl, $2 \mathrm{~mm} \mathrm{MgCl}_{2}$, 5 mм EGTA, $10 \mathrm{~mm}$ HEPES, $4 \mathrm{~mm} \mathrm{Na}{ }_{2}$ ATP, $0.3 \mathrm{~mm}$ $\mathrm{Na}_{3}$ GTP at $\mathrm{pH}$ 7.3). Granule cells were identified by their typical low whole-cell capacitance $(\sim 5 \mathrm{pF})$ and high input resistance ( $>1 G \Omega$ ) (D'Angelo et al. 1993). CNQX (6-cyano-7-nitroquinoxaline-2,3-dione, $10 \mu \mathrm{M})$ and D-APV [D-(-)-2-amino-5-phosphonopentanoic acid, $100 \mu \mathrm{M}$ ] were included in ACSF to eliminate glutamatergic synaptic currents. After the whole-cell configuration was achieved, $3 \mathrm{~min}$ were allowed for chloride to diffuse into the cells. Spontaneous $\mathrm{GABA}_{\mathrm{A}}$ synaptic currents were then continuously recorded $\left(\mathrm{V}_{\mathrm{m}}=-80 \mathrm{mV}\right)$ for $5 \mathrm{~min}$. Spontaneous $\mathrm{GABA}_{\mathrm{A}} \mathrm{R}$-mediated events were identified with custom-made programs by criteria adopted from Raastad et al. (1996). Briefly, a current deflection is considered an inhibitory postsynaptic current (IPSC) event if it fits well with a $\alpha$ function, and exhibits an amplitude four times larger than the standard deviation of baseline noise, $20 \%-80 \%$ rise time is shorter than $1 \mathrm{msec}$, and $80 \%-20 \%$ decay time longer than $5 \mathrm{msec}$. All IPSC events were later visually verified by experimenters. Decay time constant of the $\mathrm{GABA}_{\mathrm{A}} \mathrm{R}$-mediated synaptic currents was calculated by the average of all events in the 5-min recording period. Response frequency and average amplitude for each cell were also measured with custom-made programs. Data are presented as average \pm S.E.M.

\section{Results}

In adult wild-type mouse, BDNF is highly expressed in the hippocampus, neocortex, and the cerebellum (Leibrock et al. 1989; Hofer et al. 1990; Maisonpierre et al. 1990; Rocamora et al. 1993). In $B D N F$ transgenic mice, the BDNF mRNA levels, as shown in the autoradiographs (Fig. 1), are significantly elevated throughout the whole brain. In the cerebellum, dense signal is mainly located in the granule cell layer. Densitometry of the autoradiographs revealed two- to fivefold increase of BDNF mRNA level in the adult cerebellum of transgenic mouse (data not shown). Unlike endogenous BDNF expression in the wild-type mouse, which starts postnatally (Maisonpierre et al. 1990), a high level of BDNF mRNA was seen in the transgenic mouse brain as early as embryonic day 18 (Croll et al. 1999). We compared cerebellar BDNF expression in transgenic and wild-type mice during postnatal development using Northern blot analysis of total cerebellar RNA hybridized with a $B D N F$ cDNA probe (Qiao et al. 1996). As shown in Figure 2 , the expression levels of endogenous BDNF in transgenic mice are similar to those in wild types, which are not evident at postnatal day 9 (P9), low at $\mathrm{P} 13$, and relatively high at $\mathrm{P} 17$. However, in

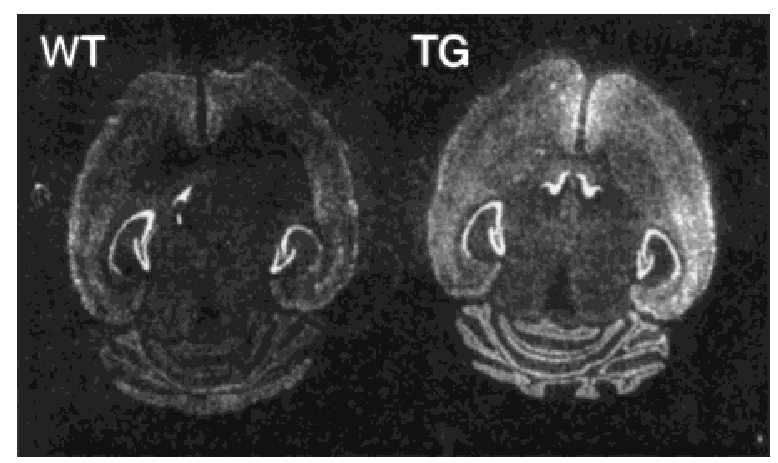

Figure 1: Expression patterns of BDNF mRNA in adult brains of wild-type (WT) and BDNF transgenic (TG) mice.

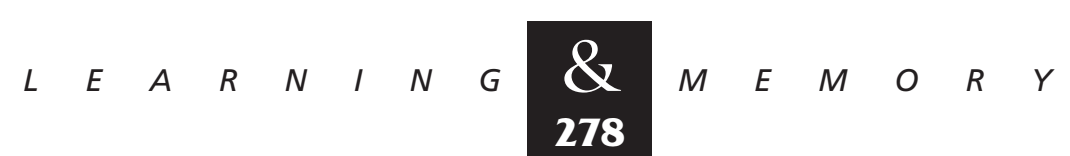




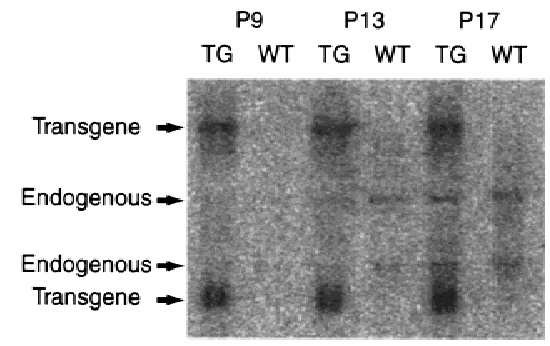

Figure 2: Northern blot analysis of BDNF mRNA levels in the cerebellum of wild-type (WT) and BDNF transgenic (TG) mice at postnatal day 9 (P9), day 13 (P13), and day 17 (P17).

transgenic mice, the $B D N F$ transgene is highly expressed at all ages examined (P9, P13, P17, and $>$ P28).

Despite the high level of transgenic BDNF expression, the mutant mouse exhibits no sign of abnormal brain development. In the cerebellar cortex, the laminar structures develop normally (Fig. $3)$. The numbers of external and internal granule cells are comparable between transgenic and wildtype mice examined at four ages, P9, P13, P17, and $\mathrm{P} 21$, suggesting that the excessive BDNF does not affect the proliferation, migration, and survival of the cerebellar granule cells.

To study Golgi cell-granule cell inhibitory synapses, cerebellar granule cells were recorded with whole-cell configuration, a blind method (Blanton et al. 1989) was used to form tight seals. After forming whole cell, a series of voltage steps were applied and cells that did not exhibit any voltageactivated currents (most likely glial cells) were discarded. Granule cells were identified by their small whole-cell capacitance $(\sim 5 \mathrm{pF})$ and large input resistance $(>1 G \Omega)$. Spontaneous $\mathrm{GABA}_{\mathrm{A}}$ receptormediated synaptic currents were recorded in the presence of $10 \mu \mathrm{M} C N Q X$ and $100 \mu \mathrm{M}$ D-APV, and were completely blocked by $30 \mu \mathrm{M}$ picrotoxin, a $\mathrm{GABA}_{\mathrm{A}}$ receptor antagonist. A total of 255 cerebellar granule cells were recorded from $B D N F$ transgenic mice and wild-type controls at four ages, P9 (wild type, $n=44$; transgenic, $n=34$ ), P13 (wild type, $n=32$; transgenic, $n=52$ ), $\mathrm{P} 17$ (wild type, $n=20$; transgenic, $n=37$ ), and P21 (wild type, $n=19 ; \quad$ transgenic, $n=19$ ). The spontaneous $\mathrm{GABA}_{\mathrm{A}}$ responses were averaged for each cell, and the decay phase of the average response was fit to a biexponential algorithm. To facilitate comparison, an amplitude-weighed average of the two decay time constants was calculated for each cell. A clear developmental decline of the decay time constant (Tia et al. 1996; L. Chen, S. Bao, X. Qiao, and R.F. Thompson, unpubl.) was observed in both transgenic and control mice (Fig. 4A). This process appeared to be accelerated in the transgenic mouse, as evidenced by a significant difference in the average decay time constant at P9 (34 transgenic cells, 44 control cells; one-way ANOVA, $F[1$, $76]=3.97, P>0.05)$. Figure $4 \mathrm{~B}$ shows spontaneous $\mathrm{GABA}_{\mathrm{A}}$ receptor-mediated synaptic responses recorded from P9 transgenic and wild-type granule cells.

A previous study (Vicario-Abejon et al. 1998) showed that prolonged treatment of cultured hippocampal neurons with exogenous BDNF caused increase in spontaneous IPSC amplitude. We compared the average IPSC amplitudes recorded from transgenic and wild-type granule cells and found that the BDNF transgene increased IPSC amplitude in the P9 group (Fig. 5A, $F[1,76]=4.05, P \leq 0.05$ ). The IPSC amplitude distribution is shifted in transgenic mice compared with that in wild-type mice (Fig. 5B).

BDNF has been shown to induce a variety of presynaptic modifications, such as increasing GABA content and GAD activity in cultured GABAergic
P9

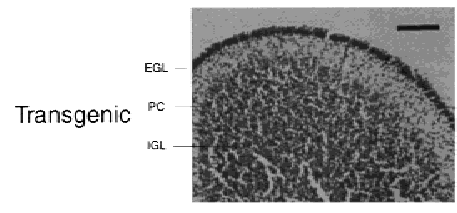

wild-type

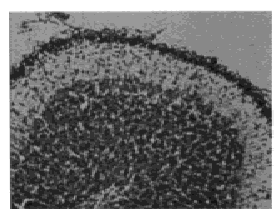

P13
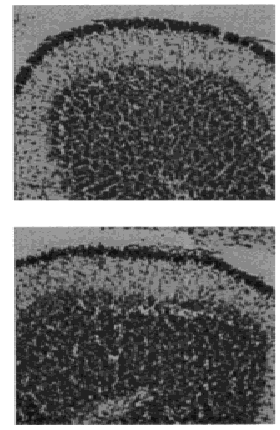

$\mathrm{P} 17$

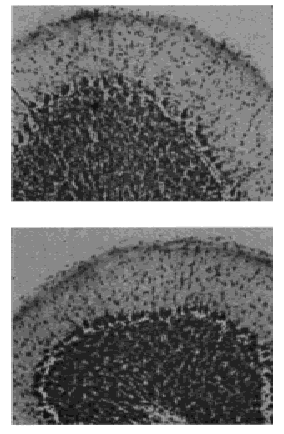

Figure 3: Laminar structures of the cerebellar cortex of wild-type and BDNF transgenic mice. The cerebellum of the transgenic mouse exhibits normal laminar structures. (EGL) external granule cell layer; (PC) Purkinje cell layer; (IGL) internal granule cell layer. Scale bar, 100 $\mu \mathrm{m}$.

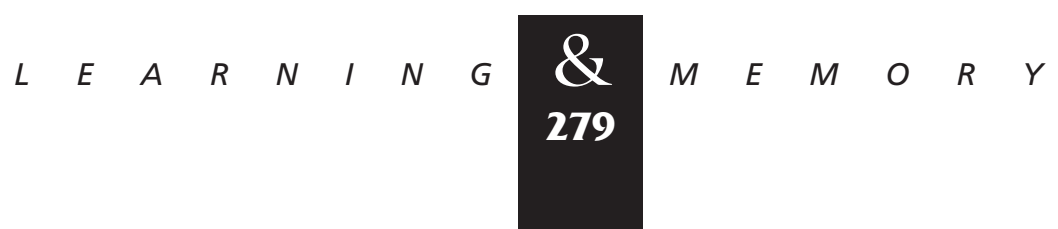


A

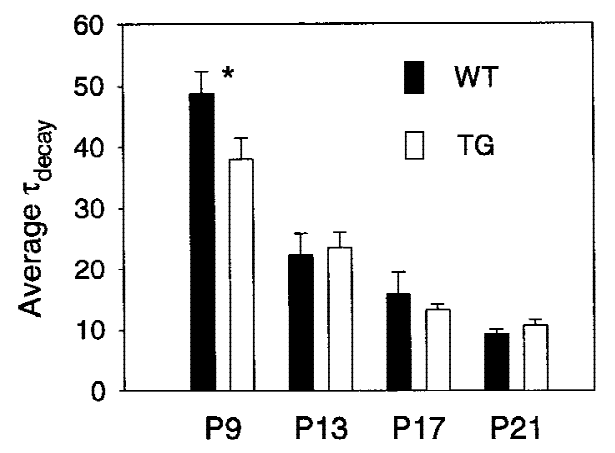

\section{B}

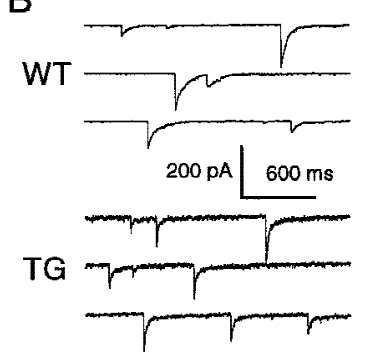

C

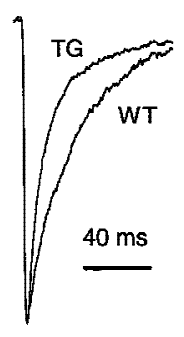

Figure 4: (A) Average decay time constant of the spontaneous IPSCs recorded from cerebellar granule cells., The IPSC decay time constants at both wild-type and the transgenic synapses exhibit developmental decrease from P9 to P21. At P9, IPSC exhibited significantly faster decay at transgenic synapses (open bars) than at wildtype synapses (black bars). $\left.{ }^{*}\right) P \leq 0.05$. (B) Examples of spontaneous IPSCs recorded from P9 cerebellar granule cells of wild-type and BDNF transgenic mice. Note the faster decay of IPSCs recorded from transgenic granule cells than those recorded from wild-type cells. (C) Examples of average IPSCs of the same wild-type and transgenic cells as in $B$.

neurons (Mizuno et al. 1994; Ventimiglia et al. 1995; Rutherford et al. 1997), promoting axonal growth and branching in cultured hippocampal inhibitory neurons (Vicario-Abejon et al. 1998), and accelerating emergence of the mature pattern of inhibitory presynaptic boutons in the visual cortex of $B D N F$ transgenic mice (Z.J. Huang, A. Kirkwood, V. Porciatti, T. Pizzorusso, M.F. Bear, L. Maffei, and S. Tonegawa, unpubl.) Granule cell IPSCs are tetrodotoxin sensitive, and therefore are caused by Golgi cell discharges (Tia et al. 1996). In the present study, we did not observe significant differences in IPSC frequency between transgenic and wild-type mice at all four age groups tested. For example, at P9, the average IPSC frequency is $7.4 \pm 1.2$ for wild type mice ( 44 cells) and $9.6 \pm 1.3$

(34 cells) for BDNF transgenic mice (see Fig. 6, one-way ANOVA, $F[1,76]=3.90, P>0.1)$.

\section{Discussion}

BDNF has been shown to modulate developing inhibitory synapse in both cell cultures and in transgenic mice. During early postnatal development, the inhibitory cerebellar Golgi cell-granule cell synapse undergoes developmental transitions in receptor composition (Laurie et al. 1992; Zheng et al. 1993; Fritschy et al. 1994; Thompson and

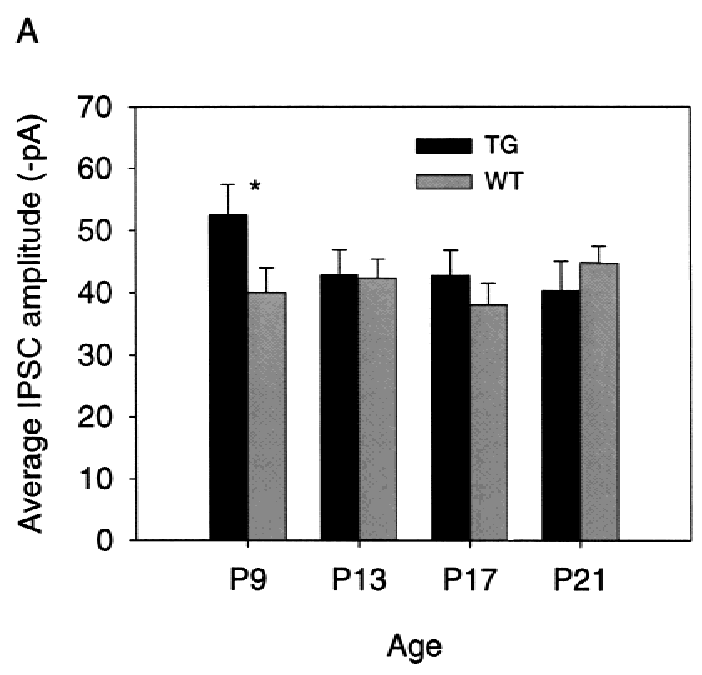

B

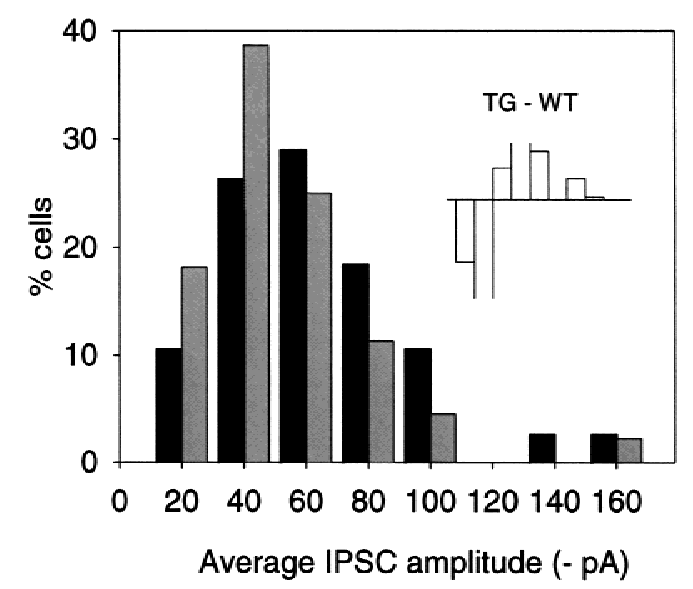

Figure 5: $(A)$ Average amplitude of the IPSCs recorded from cerebellar granule cells. (*) $P \leq 0.05$. (B) Distributions of average IPSC amplitudes of P9 cerebellar granule cells. The difference between the transgenic (black bars) and the wild-type (gray bars) distributions is plotted as an inset.

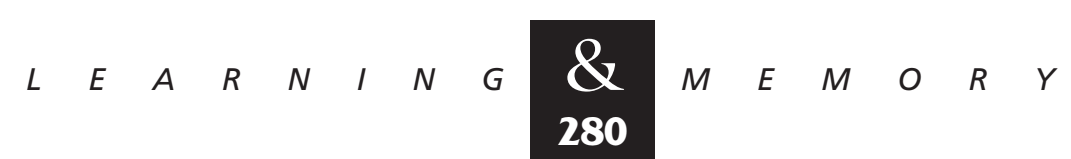


Stephenson 1994) and synaptic response kinetics (Tia et al. 1996; L. Chen, S. Bao, X. Qiao, and R.F. Thompson. unpubl.), providing a suitable system for the studying effects of neurotrophins on synapse development. Taking advantage of a transgenic mutant mouse carrying a $\beta$-actin promoterdriven human $B D N F$ transgene, we show that BDNF overexpression causes decrease in IPSC decay time constant and increase in IPSC amplitude in cerebellar granule cells at early developmental stage (i.e., P9). Because reduction in decay time constant normally occurs during the maturation process at the cerebellar Golgi cell-granule cell synapse, the decreased IPSC decay time constant may be a result of accelerated synapse maturation. BDNF is involved in many aspects of neuronal development. For example, evidence indicates that, in the cerebellum, BDNF is important for neuronal survival (Segal et al. 1992; Gao et al. 1995; Kubo et al. 1995; Minichiello and Klein 1996; Nonomura et al. 1996; Schwartz et al. 1997), differentiation (Segal et al. 1992; Minichiello and Klein 1996; Schwartz et al. 1997; Lin et al. 1998), axonal outgrowth (Segal et al. 1995) and neurite extension (Gao et al. 1995; Schwartz et al. 1997).

Although the transgenic BDNF is expressed at high levels at all ages examined (P9, P13, P17, and $>$ P28), the electrophysiological differences between the two genotypes were only observed at P9. Developmental alterations in expression patterns of TrkB and endogenous BDNF may confer this narrow time window in which the inhibitory synapse is sensitive to BDNF. For example, levels of TrkB receptor mRNAs (especially the kinase-

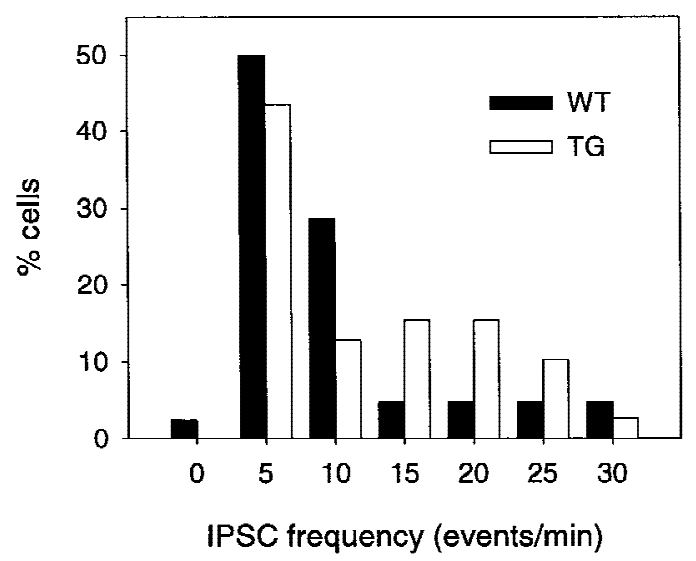

Figure 6: Distributions of spontaneous IPSC frequencies of P9 cerebellar granule cells. No difference was found between transgenic (open bars) and wild-type (black bars) IPSC frequencies. containing splicing variants) in cerebellar granule cells peak in the first postnatal week and decrease later (Segal et al. 1995). The levels of TrkB receptors may determine the responsiveness of cerebellar granule cells to BDNF. In addition, endogenous BDNF expression becomes evident at P13 and may saturate TrkB receptors (levels of which have been reduced from the peak in the first postnatal week) on the granule cells.

The accelerated synapse maturation and increased spontaneous IPSC amplitude in the present study are in general agreement with results from culture neurons (Vicario-Abejon et al. 1998). However, the effects observed in $B D N F$ transgenic mice are much less robust than those in cultures. This may be attributed to differences in cell types and experimental conditions. It is possible that cerebellar granule cells and/or Golgi cells are simply less responsive to $\mathrm{BDNF}$ than hippocampal neurons, or that a certain level of endogenous BDNF (might not be present in the culture) undercuts the effects of exogenous BDNF.

BDNF affects both presynaptic and postsynaptic neurons of GABAergic synapses. On the presynaptic side, it enhances GABA content of inhibitory neurons (Mizuno et al. 1994; Ventimiglia et al. 1995; Rutherford et al. 1997) and promotes growth and/or branching of axons and presynaptic boutons (Vicario-Abejon et al. 1998; Z.J. Huang, A. Kirkwood, V. Porciatti, T. Pizzorusso, M.F. Bear, L. Maffei, and S. Tonegawa, unpubl.). On the postsynaptic side, BDNF modulates $\mathrm{GABA}_{\mathrm{A}}$ receptor expression (Lin et al. 1998) and shifts spontaneous IPSC amplitude distribution (Vicario-Abejon et al. 1998). In the cerebellar Golgi cell-granule cell synapse, the IPSC decay kinetics are determined by postsynaptic receptor desensitization (Jones and Westbrook 1995) and the developmental decline of the IPSC decay time constant is correlated with the expression of the $\mathrm{GABA}_{\mathrm{A}}$ Receptor $\alpha 6$ subunit (Zheng et al. 1993; Tia et al. 1996). Thus, the accelerated transition of IPSC kinetics observed in the present study was likely to be caused by BDNF on granule cells. We did not observe a significant effect of transgenic $B D N F$ on IPSC frequencies (as seen in Vicario-Abejon et al. 1998), but there was considerable variation among the cells. Further biochemical analysis of the pre- and postsynaptic neurons (i.e., $\mathrm{GABA}_{\mathrm{A}}$ receptor expression in granule cells, and GABA content and GAD expression in Golgi cells, respectively) may help understand how transgenic BDNF modulates the cerebellar GABAergic synapse.

$$
\begin{array}{llllllllllllllll}
\mathbf{Q} & E & A & R & N & I & N & G & \underset{\mathbf{2 8 1}}{\mathbf{Z}} & M & E & M & O & R & Y
\end{array}
$$




\section{Acknowledgments}

Breeding pairs of the $B D N F$ transgenic mutant mouse were kindly provided by Drs. C. Suri and George D. Yancopoulos of Regeneron Pharmaceuticals. This work was supported by National Science Foundation grant IBN-9215069, National Institute of Aging grant AG-14751, National Institute of Mental Health Grant 5P20-MH52194, and a grant from Sankyo Company to Richard F. Thompson. The publication costs of this article were defrayed in part by payment of page charges. This article must therefore be hereby marked "advertisement" in accordance with 18 USC section 1734 solely to indicate this fact.

\section{References}

Bartrup, J.T., J.M. Moorman, and N.R. Newberry. 1997. BDNF enhances neuronal growth and synaptic activity in hippocampal cell cultures. Neuroreport 8: 3791-3794.

Blanton. E, J.J. Lo Turco, and A.R. Kriegstein. 1989. Whole cell recording from neurons in slices of reptilian and mammalian cerebral cortex. J. Neurosci. 30: 203-210.

Causing, C.G., A. Gloster, R. Aloyz, S.Z. Bamji, E. Chang, J. Fawcett, G. Kuchel, and F.D. Miller. 1997. Synaptic innervation density is regulated by neuron-derived BDNF. Neuron 18: 257-267.

Croll, S.D., C. Suri, D.L. Compton, M.V. Simmons, G.D. Yancopoulos, R.M. Lindsay, S.J. Weigand, J.S. Rudge, and H.E. Scharfman. 1999. Brain-derived neurotrophic factor (BDNF) transgenic mice exhibit passive avoidance deficits, increased seizure severity, and in vitro hyperexcitability in the hippocampus and entorhinal cortex. Neuroscience (in press).

D'Angelo, E., P. Rossi, and V. Taglietti. 1993. Different proportions of $\mathrm{N}$-methyl-D-Aspartate and non- $\mathrm{N}$-methyl-D-Aspartate receptor currents at the mossy fiber-granule cell synapse of developing rat cerebellum. Neurosci. 53: 121-130.

Fritschy, J.M., J. Paysan, A. Enna, and H. Mohler. 1994. Switch in the expression of rat $\mathrm{GABA}_{\mathrm{A}}$-receptor subtypes during postnatal development: An immunohistochemical study. J. Neurosci. 14: 5302-5324.

Gao, W., J.L. Zheng, and M. Karihaloo. 1995.

Neurotrophin-4/5 (NT-4/5) and brain-derived neurotrophic factor (BDNF) act at later stages of cerebellar granular cell differentiation. J. Neurosci. 15: 2656-2667.

Ghosh, A., J. Carnahan, and M. E. Greenberg. 1994. Requirement of BDNF in activity-dependent survival of cortical neurons. Science 263: 1618-1723.

Hofer, M., S.R. Pagluisi, A. Hohn, J. Leibrock, and Y.A. Barde. 1990. Regional distribution of brain-derived neurotrophic factor mRNA in the adult mouse brain. EMBO J. 9: 2459-2464.

Jones, M.V. and G.L. Westbrook. 1995. Desensitized states prolong $\mathrm{GABA}_{\mathrm{A}}$ channel responses to brief agonist pulses. Neuron 15: 181-191.

Kubo, T., T. Nonomura, Y. Enokido, and H. Hatanaka. 1995. Brain-derived neurotrophic factor (BDNF) can prevent apoptosis of rat cerebellar granule neurons in culture. Dev. Brain Res. 85: 249-258.

Laurie, D.J., W. Wisden, and P.H. Seeburg. 1992. The distribution of thirteen $\mathrm{GAGA}_{\mathrm{A}}$ receptor subunit mRNAs in the rat brain. III. Embryonic and postnatal development. J. Neurosci. 12: 4151-4172.

Leibrock, J., F. Lottspeich, A. Hohn, M. Hofer, B. Hengerer, P. Masiakowski, H. Thoenen, and Y.A. Barde. 1989. Molecular cloning and expression of brain-derived neurotrophic factor. Nature 341: 149-152.

Lin, X., H. Cui, and R.F. Bulleit. 1998. BDNF accelerates gene expression in cultured cerebellar granule neurons. Dev. Brain Res. 105: 277-286.

Maisonpierre, P.C., L. Belluscio, B. Friedman, R.F. Alderson, S.J. Wiegand, M.E. Furth, R.M. Lindsay, and G.D. Yancopoulos. 1990. NT-3, BDNF, and NGF in the developing rat nervous system: Parallel as well as reciprocal patterns of expression. Neuron 5: 501-509.

McAllister, A.K., D.C. Lo, and L.C. Katz. 1995. Neurophins regulate dendritic growth in developing visual cortex. Neuron 15: $791-803$.

Minichiello, L. and R. Klein. 1996. TrkB and TrkC neurotrophin receptors cooperate in promoting survival of hippocampal and cerebellar neurons. Genes \& Dev. 10: 2849-2858.

Mizuno, K., J. Carhahan, and H. Nawa. 1994. Brain-derived neurotrophic factor promotes differentiation of striatal GABAergic neurons. Dev. Biol. 165: 243-256.

Nonomura, Y., T. Kubo, T. Oka, K. Shimoke, M. Yamada, Y. Enokido, and H. Hatanaka. 1996. Signaling pathways and survival effects of BDNF and NT-3 on cultured cerebellar granule cells. Dev. Brain Res. 97: 42-50.

Phillips, H.S., J.M. Hains, G.R. Laramee, A. Rosenthal, and J.W. Winslow. 1990. Widespread expression of BDNF but not NT3 by target areas of basal forebrain cholinergic neurons. Science 250: 290-294.

Qiao, X., F. Hefti, B. Knusel, and J.L. Noebels. 1996. Selective failure of brain-derived neurotrophic factor mRNA expression in the cerebellum of stargazer, a mutant mouse with ataxia. J. Neurosci. 16: 640-648.

Raastad, M., B.R. Johnson, and O. Kiehn. 1996. The number of postsynaptic currents necessary to produce locomotor-related cyclic information in neurons in the neonatal rat spinal cord. Neuron 17: 729-738.

Rocamora, N., F.J. Garcia-Ladona, J.M. Palacios, and G. Mengod. 1993. Differential expression of brain-derived

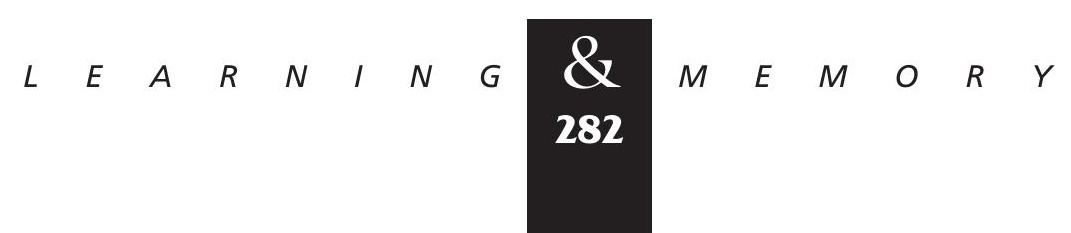


neurotrophic factor, neurotrophin-3, and low-affinity nerve growth factor receptor during the postnatal development of the rat cerebellar system. Mol. Brain Res. 17: 1-8.

Rutherford, L.C., A. DeWan, H.M. Lauer, and G.G.

Turrigiano. 1997. Brain-derived neurotrophic factor mediates the activity-dependent regulation of inhibition in neocortical cultures. J. Neurosci. 17: 4527-4535.

Rutherford, L.C., S.B. Nelson, and G.G. Turrigiano. 1998. BDNF has opposite effects on the quantal amplitude of pyramidal neuron and interneuron excitatory synapses. Neuron 21: 521-530.

Schwartz P.M., P.R. Borghesani, R.L. Levy, S.L. Pomeroy, and R.A. Segal. 1997. Abnormal cerebellar development and foliation in BDNF-/- mice reveals a role for neurotrophins in CNS patterning. Neuron 19: 269-281.

Segal, R.A., H. Takahashi, and R.D. McKay. 1992. Changes in neurotrophin responsiveness during the development of cerebellar granule neurons. Neuron 9: 1041-1052.

Segal, R.A., S.L. Pomeroy, and C.D. Stiles. 1995. Axonal growth and fasciculation linked to differential expression of BDNF and NT3 receptors in developing cerebellar granule cells. J. Neurosci. 15: 4970-4981.

Thompson, C.L. and F.A. Stephenson. 1994. GABA $\mathrm{A}_{\mathrm{A}}$ receptor subtypes expressed in cerebellar granule cells: A

developmental study. J. Neurochem. 62: 2037-2044.

Tia, S., J.F. Wang, N. Kotchabhakdi, and S. Vicini. 1996. Developmental changes of inhibitory synaptic currents in cerebellar granule neurons: Role of $\mathrm{GABA}_{\mathrm{A}}$ receptor $\alpha 6$ subunit. J. Neurosci. 16: 3630-3640.

Ventimiglia, R., P.E. Mather, B.E. Jones, and R.M. Lindsay. 1995. The neurotrophins BDNF, NT-3 and NT-4/5 promote survival and morphological and biochemical differentiation of striatal neurons in vitro. Eur. J. Neurosci. 7: 213-222.

Vicario-Abejon, C., C. Collin, R.D. McKay, and M. Segal. 1998. Neurotrophins induce formation of functional excitatory and inhibitory synapses between cultured hippocampal neurons. J. Neurosci. 18: 7256-7271.

Widmer H.R. and F. Hefti. 1994. Stimulation of GABAergic neuron differentiation by NT4/5 in cultures of rat cerebral cortex. Dev. Brain Res. 80: 279-284.

Zheng, T., M.R. Santi, P. Bovolin, L.N. Marlier, and D.R. Grayson. 1993. Developmental expression of the alpha 6 $\mathrm{GABA}_{\mathrm{A}}$ receptor subunit mRNA occurs only after cerebellar granule cell migration. Dev. Brain Res. 75: 91-103.

Received May 5, 1999; accepted in revised form June 21, 1999.

$$
\begin{array}{llllllllllllllll}
\hline & E & A & R & N & I & N & G & \mathbf{Q} & M & E & M & 0 & R & Y
\end{array}
$$




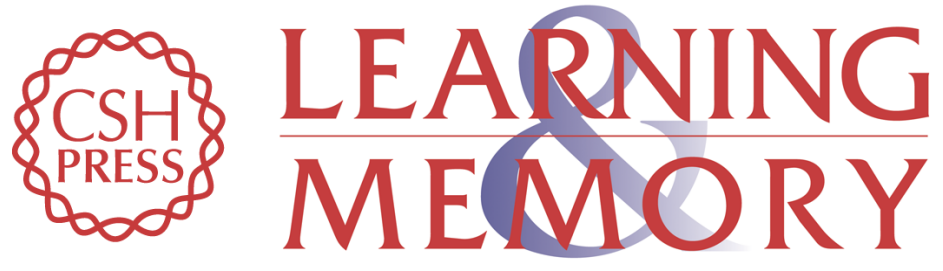

\section{Transgenic Brain-Derived Neurotrophic Factor Modulates a Developing Cerebellar Inhibitory Synapse}

Shaowen Bao, Lu Chen, Xiaoxi Qiao, et al.

Learn. Mem. 1999, 6:

Access the most recent version at doi:10.1101//m.6.3.276

References This article cites 32 articles, 11 of which can be accessed free at: http://learnmem.cshlp.org/content/6/3/276.full.htmI\#ref-list-1

License

Email Alerting Receive free email alerts when new articles cite this article - sign up in the box at the Service top right corner of the article or click here. 